\title{
Postoperative radiotherapy-induced morbidity in rectal cancer
}

\author{
M. Garay Burdeos, M. García-Botella, V. Viciano Pascual, M. D. Torregrosa Macías ${ }^{1}$ J. Aguiló Lucia, \\ M. Ata, M. C. Muñoz Alonso and J. García del Caño \\ Department of General and Digestive Surgery. 'Oncology Section (Department of Internal Medicine). Lluís Alcanyís \\ Hospital. Xàtiva, Valencia. Spain
}

\begin{abstract}
Objectives: we analyzed long-term morbidity and bowel function alteration after postoperative radiotherapy for rectal cancer following resection with anastomosis.

Patients and methods: thirty-seven patients who underwent surgery with intention to cure and a minimal follow-up period of 3 years were included. These patients were divided into two groups: in the first group, 14 patients received postoperative chemo-radiotherapy, 5-fluorouracil plus folinic acid, and 45 Gy plus 5 Gy boost. In the second group, there were 23 patients regarded as controls. We designed a questionnaire about their bowel function and analyzed the morbidity detected in their follow-up.

Results: the group that was treated with postoperative chemo-radiotherapy had more daily bowel movements ( $p=$ $0.03)$ and night-time movements $(p=0.04)$; incontinence (69.2 versus $17.4 \%$ in the control group; $p=0.002)$, and perianal skin irritation $(\mathrm{p}=0.04)$ versus the control group. Although without meaningful differences, the group under treatment wore a pad more often, had more defecatory urgency, could distinguish worse gas from stool, and needed more frequently antidiarrheal measures. Major complications were present in $28.6 \%$ of the under-treatment group: three intestinal resections were performed due to actinic stenosis; one patient had a residual stercoral fistula; another had several occlusive crises solved with medical treatment.

Conclusions: postoperative chemo-radiotherapy had a high morbidity rate, which determined a significant alteration in quality of life. Accuracy in indication is therefore necessary, as well as a consideration of other alternatives for treatment, such as preoperative chemo-radiotherapy and total mesorectal excision.
\end{abstract}

Key words: Rectal cancer. Chemo-radiotherapy. Morbidity.

Recibido: 12-11-03.

Aceptado: 09-03-04.

Correspondencia: Miguel Garay Burdeos. Servicio de Cirugía Oral y Digestiva. Hospital Lluis Alcanyís. Carretera Xàtiva-Silla, km. 2. 46800 Xàtiva. Valencia. Tel.: 962289 563. e-mail: miguelgaray59@hotmail.com
Garay Burdeos M, García-Botella M, Viciano Pascual V, Torregrosa Macías MD, Aguiló Lucia J, Ata M, Muñoz Alonso MC, García del Caño J. Postoperative radiotherapy-induced morbidity in rectal cancer. Rev Esp Enferm Dig 2004; 96: 765-772.

\section{INTRODUCTION}

The surgical treatment of rectal cancer is burdened with a high percentage of local recurrence (1). It varies from 20 to $70 \%$ according to tumor stage. In the last few years a great effort has been made in order to decrease disease progression, and the management of rectal cancer has substantially changed due to advances in surgical techniques, changes in radiotherapy technology, and the emerging role of some chemotherapeutic agents such as oxaliplatin. All this has meant continuous changes in standard therapeutic protocols (2).

Several studies have proved that chemo-radiotherapy, either pre- or post-operative, improves survival time and decreases local recurrence (2-6). Therefore, radiotherapy (RT) is recommended as a part of rectal cancer treatment since 1990 (7-11). At the same time, surgical modifications, such as total mesorectal excision (TME), have succeeded in decreasing local recurrence below $10 \%$ even in high-risk patients $(12,13)$.

Nevertheless, radiotherapy is not free from side effects, which may have a great impact on the patient's quality of life (14). Short-term morbidity and mortality have been analyzed in several studies, but studies about long-term morbidity are rare (1,14-16).

Difficulties for such a post-radiotherapy morbidity study may include various factors: concern regarding metastatic disease or local recurrence, which may lead to underestimate local alterations associated with radiotherapy; various chemotherapy protocols (combined or not with radiotherapy), and the different radiation tech- 
niques used-dose fractionation and limited-field radiation $(14,17)$.

The objective of this study is to assess the long-term side effects of postoperative radiotherapy and its impact on anorectal function.

\section{PATIENTS AND METHODS}

Clinical records of patients who underwent surgery for rectal cancer in the Department of Surgery at the Hospital "Lluís Alcanyís" during the period 1993-1998 were retrospectively reviewed. There was a group of 68 patients who fulfilled the following criteria: tumor location was below $15 \mathrm{~cm}$ from the anal margin, there was no invasion of adjacent organs, and all of them had been operated using anterior resection of the rectum with primary anastomosis and no diverting stoma. Nine patients of this group were excluded due to metastatic disease at the time of surgery; 13 died because of disease progression; 2 of them needed a temporary diversion due to an anastomotic leak, as this complication itself could alter bowel function; 1 patient happened to have a non-resectable gastric cancer, and 6 patients could not be contacted. The remaining 37 patients were included in this study and were divided up in two groups: the first one included those 14 subjects who had been treated with postoperative chemoradiotherapy (CRT); the other group, which was considered the control group, included the remaining 23 who did not receive radiotherapy. In the control group there were two patients whose stage was 0 , as they suffered from big, degenerated villous tumors (Tis) that required an anterior resection.

The treatment schedule of those 14 patients in the CRT group was as follows: two chemotherapy cycles with 5 -fluorouracil $\left(425 \mathrm{mg} / \mathrm{m}^{2}\right)$ plus folinic acid $\left(20 \mathrm{mg} / \mathrm{m}^{2}\right)$, followed by radiotherapy plus 5-fluorouracil concurrently for the first and last three days, reaching a total dose of $45 \mathrm{~Gy}$, and adding at the end a presacral boost of 5, 4 or 9 Gy in relation to their body volume. Treatment was completed with two more chemotherapy cycles with 5-fluorouracil and folinic acid.

Radiotherapy was delivered through a high-energy linear accelerator. Radiation technique was isocentral with 4 fields into the pelvis and lateral fields in the presacral boost, a fractionation of $180 \mathrm{cGy}$ per each session until the full dose was reached. Radiation in the prone position and astringent diet were used as protective measures to minimize the toxicity of radiotherapy.

Along the year 2002, all patients included in this study were interviewed in order to assess their bowel function, and all their clinical records were revised to detect all possible major complications suffered by these patients after discharge from hospital. In this way we assured a minimal follow-up of 3 years after completing the treatment of rectal cancer. The interview gathered: number of daily bowel movements and how many at night time, consistency of stool (liquid, semisolid, or solid), incontinence and its frequency (occasional $\leq$ once per week; frequent $>$ once per week), soiling, need to wear a pad, ability to distinguish between flatus and stool, urgency (if they were able to defer defecation for more than 15 minutes), tenesmus, perianal skin irritation, bleeding, mucorrhea, and need for antidiarrheal measures (diet, medication). Quality of life questionnaires specifically made for colorectal cancer, as the QLQ-CR 38 developed by EORTC, were not used since at the time of this study they had not been fully adapted and validated regarding Spanish cultural features (18).

Follow-up and anorectal function complications detected were analyzed according to the answers in the written interview. Chi-square testing was used for percentage comparisons between both groups.

\section{RESULTS}

We did not find any significant differences between both groups regarding sample characteristics -age, sex, and tumor level- except for tumor stage (Table I). We also could not find any noteworthy differences in the postoperative complications of both groups. Colorectal anastomosis bleeding in the CRT group was solved by endoscopic coagulation. Three minimal anastomotic leaks in the control group (which had poor clinical manifestation and which were exteriorized by a drain) had a good outcome in a few days with conservative treatment (parenteral nutrition and antibiotics).

Survey results showed (Table II) that the CRT group had a mean (3.3) of bowel movements per day that was

Table I. Description of sample groups

\begin{tabular}{lccc}
\hline & $C R T$ & Non-RT & $p$ \\
\hline Male/Female & $8 / 6$ & $13 / 10$ & n.s \\
Age* & $69(48-77)$ & $68.5(53-84)$ & n.s. \\
Tumor level* & $10(6-12)$ & $10(6-15)$ & n.s. \\
Tumor stage & & & 0.03 \\
0 & - & 2 & \\
I & - & 7 & \\
II & 5 & 8 & \\
III & 9 & 6 & \\
Postoperative complications & 6 & 10 & n.s. \\
Anastomotic bleeding & 1 & - & \\
Paralytic ileus & 1 & - & \\
Wound serome & 2 & 1 & \\
Wound infection & - & 4 & \\
Pneumonia & 1 & - & \\
Urinary infection & - & 1 & \\
Anastomotic leak ${ }^{(1)}$ & - & 3 &
\end{tabular}

*Median (range); (1) without abdominal repercussion, solved with conservative treatment. 
Table II. Anorectal function after 3 years of the end of treatment

\begin{tabular}{lccc}
\hline & $\begin{array}{c}\text { CRT } \\
\text { (14 patients) }\end{array}$ & $\begin{array}{c}\text { Non-RT } \\
(23 \text { patients) }\end{array}$ & $p$ \\
\hline Stool consistency & & & 0.04 \\
$\quad$ Soft & $462 \%$ & $13 \%$ & \\
$\quad$ Normal & $53.8 \%$ & $87 \%$ & \\
Number of bowel movements* & $3.3(1-7)$ & $1.9(1-4)$ & 0.03 \\
Movements at night & $30.8 \%$ & $4.2 \%$ & 0.04 \\
Incontinence & & & 0.002 \\
$\quad$ None & $30.8 \%$ & $82.6 \%$ & \\
$\quad$ Occasional & $46.1 \%$ & $4.4 \%$ & \\
$\quad$ Frequent & $23.1 \%$ & $13 \%$ & \\
Wear a pad & $30.8 \%$ & $13 \%$ & n.s. \\
Unable to differentiate stool/flatus & $30.8 \%$ & $30.4 \%$ & n.s. \\
Defecatory urgency & $38.5 \%$ & $21.7 \%$ & n.s. \\
Perianal skin irritation & $30.8 \%$ & $4.3 \%$ & 0.04 \\
Antidiarrheal measures & & & n.s. \\
$\quad$ Diet & $30.8 \%$ & $13 \%$ & \\
$\quad$ Medication & $15.4 \%$ & $8.6 \%$ & \\
$\quad$ None & $53.8 \%$ & $78.3 \%$ & \\
\hline
\end{tabular}

*Median (range).

significantly higher $(\mathrm{p}=0.03)$ than the control group (1.9). A higher percentage of CRT group patients, $30.8 \%$, had bowel movements at night-time versus $4.2 \%$ in the control group $(\mathrm{p}=0.04)$. There were also significant differences detected in stool consistency: $46.2 \%$ of patients who had received radiotherapy had softer stools, versus $13 \%$ in the control group.

In all, $69.2 \%$ of patients in the CRT group suffered from incontinence (most of them occasionally), though often episodes were also present in a high percentage. However, in the control group, incontinence was only present in $17.4 \%$ of patients and that was statistically significant $(p=0.002)$. We noticed, however without significant differences, that a high percentage of patients in the CRT group needed to wear a pad, while only $13 \%$ in the control group needed it. We did not find differences between both groups regarding their capacity to discriminate between flatus and stool.

Defecation urgency was relatively frequent in both groups, and we did not find significant differences between both groups. However, a high percentage (38.5\%) of patients in the CRT group had problems to delay discharge more than 15 minutes, while only $21.7 \%$ had such urgency in the control group. Perianal irritation was more common in patients within the CRT group $(\mathrm{p}=0.04)$.

Although an important number of patients had some type of anorectal dysfunction, only $31 \%$ of them needed some dietetic or pharmacologic measures, loperamide being the most widely used drug.

During follow-up, four patients $(28.6 \%)$ in the CRT group suffered from major complications with recurrent obstructive episodes at the end of radiotherapy. Three of them needed surgery. An ileal resection was performed in two of them due to stricture caused by bowel radiation.
They also needed dilatation of colorectal anastomotic strictures produced by radiotherapy. In one patient, a Hartmann's procedure had to be performed because of an anastomotic fistula in a stiff and thickened rectum four months after radiotherapy completion. This patient still suffers from persistent intestinal fistula with sporadic fecal soilage from the rectal stump. None of the other patients in the CRT group and the control group has ever presented any other major complication during follow up.

\section{DISCUSSION}

Radiotherapy is regarded as another component of the therapeutical armamentarium for rectal cancer, its essential aim being to decrease local recurrence (2-11); it is even more effective when associated with chemotherapy. Chemo-radiotherapy has shown a remarkable decrease in recurrence and a better survival rate (6). However, several publications $(1,3,5,15-17,19)$ have stated the adverse effects of radiotherapy, both pre- and post-operative.

Acute morbidity affects most patients in varying degrees, and manifests as gastrointestinal, hematological, and dermatologic disorders, as well as lumbosacral plexopathies $(1,7,14,19)$. Although we had no mortality in our study, as in other studies (5), the literature describes $(1,3,7)$ a small percentage of patients that suffer from severe complications due to sepsis and gastrointestinal problems. That places mortality rate secondary to radiotherapy in a level between 0.3 and $18 \%$. Several authors attribute this considerable morbi-mortality to patient-related factors (age, diabetes and atherosclerotic disease), type of drugs used, and radiation technique.

However, radiation induces several disorders that produce late adverse effects $(1,14-16)$, as intestinal obstruction, actinic enteritis, and proctitis, with figures ranging between 4 and $15 \%$. This percentage was greater in our study (28\%), probably because of sample size. Out of four patients with symptomatic actinic disorders, three had to be operated upon; however, they were not fully free from symptoms afterwards, because of adhesions and permanent rectal actinic changes. One patient even had a permanent rectal fistula to the abdominal wall in spite of going through a Hartman's operation that excluded intestinal transit.

Functional changes of the pelvic floor have not been properly documented $(1,14-16,20)$, and there are few reports that analyze long-term functional changes. Most studies are related to survival, local relapse, and changes following surgical technique (14).

In accordance with other similar reports $(1,15,16)$, we confirmed the toxicity of postoperative chemo-radiotherapy. It causes an important detrimental effect on bowel function, with softer stools, increased number of daily bowel movements (daytime and at night), incontinence, soiling, and perianal skin irritation. Other changes described $(1,15)$, as the need to wear a pad, defecation urgency, and the use of antidiarrheal measures showed non- 
significant differences, although they were more frequent in the CRT group, probably also because of sample size $(1,14,15,20)$. The causes of these functional changes are related to reduced rectal capacity and compliance, as well as to disorders in anorectal pressures.

The damage to anorectal function and the sequels of actinic lesions, together with the frequent need of medical or surgical treatments to improve these symptoms, may significantly modify the quality of life for such patients $(1,14)$.

In the 1990s, a number of clinical trials were carried out with preoperative radiotherapy, and it was suggested that radiotherapy was better administered before surgical procedures $(4,6,10)$, as it would lead to less side-effects and complications, as well as to a lower chance of small bowel damage.

However, since total mesorectal excission in rectal cancer has become standard, controversy has arisen on the need of radiotherapy $(9,12,13,21,22)$, due to its low local relapse rate, similar to the rate obtained with preoperative chemo-radiotherapy. Heald et al. (12) revealed that TME diminishes local recurrence rates to $2 \%$ in 10 years' time after curative resections, which suggests that total mesorectal excission is the main determinant for outcome. Survival is 80 at 10 years in curative resections. Nevertheless, it has considerable postoperative complications, though not greater than those of other techniques, and as many as $17 \%$ anastomotic leaks. This is why a temporary ileostomy is recommended when the anastomosis is placed at less than $6 \mathrm{~cm}$ from the anal margin $(12,23,24)$. Vascular infiltration, Dukes' stage, and circumferential margin involvement are the only significant predictors of local recurrence in Heald's experience.

Therefore, having postoperative RT morbidity and local recurrence rates with both TEM and CRT in mind, the pending question is whether the present-day treatment for rectal cancer is TME associated with preoperative chemo-radiotherapy or not $(4,24,25)$. The answer to this question is still expected from the results of trials currently in progress. Furthermore, we believe that greater selectivity and stress are needed when defining those cases individually analyzed and based on prognostic factorsthat may benefit from neoadjuvant treatment $(6,24,25)$.

Rising overall and disease-free survival, decreasing local recurrence rates, and having fewer postoperative complications should not be the only goal in the treatment of rectal cancer. We must provide our patients with the best quality of life. So, we should be stricter at the time of prescribing postoperative chemo-radiotherapy, we should have in mind the loss in quality of life that it involves, and maybe we should keep it only for a few patients with a high risk of progression.

\section{REFERENCES}

1. Ooi BS, Tjandra JJ, Green MD. Morbidities of adjuvant chemotherapy and radiotherapy for resectable rectal cancer. Dis Colon Rectum 1999; 42: 403-18.
2. Gastrointestinal Tumor Study Group. Prolongation of the disease-free interval in surgically treated rectal carcinoma. N Engl J Med 1985; 312: 1465-72.

3. Colorectal Cancer Collaborative Group. Adjuvant radiotherapy for rectal cancer: a systematic overview of 8507 patients from 22 randomised trials. Lancet 2001; 358: 1291-304.

4. Bosset JF, Mantion G, Lorchel F, Magnin V, Pelissier EP, Gerard JP, et al. Adjuvant and neoadjuvant radiation Therapy for rectal cancer. Sem Oncol 2000; 27: 60-5.

5. Martín de Vidales C, Cerezo L, Vazquez de la Torre ML, Zapatero A, Del Cerro E, Pinar B, et al. Estudio comparativo en el adenocarcinoma de recto: radioterapia preoperatoria o postoperatoria. Rev Esp Enferm Dig 1995; 87: 199-204.

6. Sauer R. Adjuvant and neoadjuvant radiotherapy and concurrent radiochemotherapy for rectal cancer. Pathol Oncol Res 2002; 8: 7-17.

7. Marjinen CAM, Glimelius B. The role of radiotherapy in rectal cancer. Eur J Cancer 2002; 38: 943-52.

8. Sociedad Valenciana de Cirugía. Guía de práctica clínica en el cáncer colorrectal. Generalitat Valenciana. Consellería de Sanitat. Valencia, 2002.

9. Tratamiento adyuvante del cáncer colorrectal. En: Lledó S, ed. Cirugía Colorrectal. Asociación Española de Cirujanos. Madrid: Arán Ediciones. 2000.

10. Glimelius B. Radiotherapy in rectal cancer. Br Med Bull 2002; 64: 14157.

11. Minsky BD, Coia L, Haller DG, Hoffman J, John M, Landry J, et al. Radiation therapy for rectosigmoid and rectal cancer: results of the 19921994 patterns of care process survey. J Clin Onc 1998; 16: 2542-7.

12. Heald RJ, Moran BJ, Ryall RDH, Sexton R, MacFarlane JK, et al. Rectal cancer. The Basingstoke experience of total mesorectal excision, 19781997. Arch Surg 1998; 133: 894-9.

13. Bülow S, Christensen IJ, Harling H, Kronborg O, Fenger C. Recurrence and survival after mesorectal excision for rectal cancer. Br J Surg 2003; 90: 974-80.

14. Reis ED, Vine AJ, Heimann T. Radiation damage to the rectum and anus: pathophysiology, clinical features and surgical implications. Colorectal Dis 2002; 4: 2-12.

15. Kollmorgen CF, Meagher AP, Wolff BG, Pemberton JH, Martenson JA, Illstrup DM. The long-term effect of adjuvant postoperative chemoradiotherapy for rectal carcinoma on bowel function. Ann Surg 1994; 220: 67682.

16. Nathanson DR, Espat NJ, Nash GM, D’Alessio M, Thaler H, Minsky $\mathrm{BD}$, et al. Evaluation of preoperative and postoperative radiotherapy on long-term functional results of straight coloanal anastomosis. Dis Colon Rectum 2003; 46: 888-94.

17. Coia LR, Gunderson LL, Haller D, Hoffman J, Mohiuddin M, Tepper JE, et al. Outcomes of patients receiving radiation for carcinoma of the rectum. Results of the 1988-1989 patterns of care study. Cancer 1999; 86: 1952-8.

18. Arraras JI, Vera R, Manterola A, Martínez M, Arias F, Martínez E, et al. El cuestionario de calidad de vida para cáncer colorrectal. EORTC QLQCR38. Estudio de validación para nuestro país. Oncología 2003; 26 (9): 285-92.

19. Marijnen CAM, Kapiteijn E, Van de Velde CJH, Martijn H, Steup WH, Wiggers T, et al. Acute side effects and complications after short-term preoperative radiotherapy combined with total mesorectal excision in primary rectal cancer: report of a multicenter randomized trial. J Clin Oncol 2002; 20: 817-25.

20. Ammann K, Kirchmayr W, Klaus A, Mühlmann G, Kafka R, Oberwalder $\mathbf{M}$, et al. Impact of neoadjuvant chemoradiation on anal sphincter function in patients with carcinoma of the midrectum and low rectum. Arch Surg 2003; 138: 257-61.

21. Dahlberg M, Glimelius B, Pahlman L. Changing strategy for rectal cancer is associated with improve outcome. Br J Surg 1999; 86: 379-84.

22. Wiggers T, Van de Velde CHJ. Reduction by half. The need for standarised surgical technique in studies of radiotherapy for rectal cancer. Eur J Surg 1999; 165: 407-9.

23. MacFarlane JK, Ryall RDH, Heald RJ. Mesorectal excision for rectal cancer. Lancet 1993; 341: 457-60.

24. Kapiteijn E, Kranenbarg EK, Steup WH, et al. Total mesorectal excision (TME) with or without preoperative radiotherapy in the treatment of primary rectal cancer. Eur J Surg 1999; 165: 410-20.

25. Simunovic M, Sexton R, Rempel E, Moran BJ, Heald RJ. Optimal preoperative assessment and surgery for rectal cancer may greatly limit the need for radiotherapy. Br J Surg 2003; 90: 999-1003. 


\title{
Morbilidad de la radioterapia postoperatoria en el cáncer de recto
}

\author{
M. Garay Burdeos, M. García-Botella, V. Viciano Pascual, M. D. Torregrosa Macías , J. Aguiló Lucia, \\ M. Ata, M. C. Muñoz Alonso y J. García del Caño
}

Servicio de Cirugía General y Digestiva. 'Sección de Oncología (Servicio de Medicina Interna). Hospital Lluís Alcanyís. Xàtiva, Valencia

\section{RESUMEN}

Objetivos: analizar la morbilidad y alteración del funcionalismo rectal a largo plazo de la radioterapia postoperatoria tras resección con anastomosis en el cáncer de recto.

Material y métodos: se incluyen 37 pacientes intervenidos con intención curativa y con una evolución mínima de 3 años. Se dividen en dos grupos: 14 tratados con quimio-radioterapia postoperatoria, 5-fluoracilo más ác. folínico y $45 \mathrm{~Gy}$ más "boost" de 5 Gy y 23 no tratados utilizados como grupo control. Se realizó una encuesta sobre su funcionalismo rectal y se analizó la morbilidad detectada en el seguimiento.

Resultados: el grupo tratado con quimio-radioterapia postoperatoria presentaba mayor frecuencia defecatoria diaria $(p=0,03)$ y nocturna $(p=0,04)$; incontinencia en el $69,2 \%$ frente al $17,4 \%$ del grupo control $(p=0,002)$ y mayor irritación perianal $(p=0,04)$. Aunque sin diferencias significativas, el grupo tratado precisó usar más frecuentemente compresas, tenía más urgencia defecatoria, diferenciaba peor gases y heces y precisó más medidas antidiarreicas. El 28,6\% del grupo tratado presentaron complicaciones mayores: 3 resecciones intestinales por estenosis actínicas quedando uno con una fístula estercorácea residual; otro tuvo varias crisis suboclusivas resueltas con tratamiento conservador.

Conclusiones: la quimio-radioterapia postoperatoria tiene una alta tasa de morbilidad, que condiciona una alteración importante de la calidad de vida por lo que es necesario sopesar bien la indicación y tener presente las posibilidades que se abren con la quimio-radioterapia preoperatoria y la excisión mesorrectal total.

Palabras clave: Cáncer de recto. Quimio-radioterapia. Morbilidad.

\section{INTRODUCCIÓN}

La cirugía del cáncer de recto está gravada con un alto porcentaje de recidiva local (1), variando desde el 20 hasta el $70 \%$ en función del estadio tumoral. En los últimos años, con el fin de reducir la progresión de la enfermedad, el tratamiento del cáncer de recto ha variado sustancialmente por los avances en la técnica quirúrgica, las modificaciones en la tecnología radioterápica y las evidencias del papel que pueden desempeñar algunos agentes quimioterápicos como el oxaliplatino. Todo ello ha supuesto modificaciones constantes en los protocolos terapéuticos utilizados (2).

Diversos estudios han demostrado que la quimiorradioterapia, pre o postoperatoria, mejora la supervivencia y reduce la recidiva local (2-6), por lo que desde 1990 la radioterapia (RT) está recomendada como parte del tratamiento del cáncer de recto (7-11). A su vez, variaciones técnicas como la excisión mesorrectal total (EMT) han conseguido reducir la tasa de recidiva local a menos del $10 \%$, incluso en pacientes de alto riesgo $(12,13)$.

Sin embargo, la radioterapia no está exenta de efectos secundarios, que pueden tener un impacto importante en la calidad de vida de los pacientes (14). La morbi-mortalidad a corto plazo ha sido estudiada en diversos ensayos, aunque hay pocos referidos a la morbilidad a largo plazo (1,14-16).

Las dificultades para el estudio de la morbilidad post-radioterapia pueden deberse a varios factores: la preocupación por la recidiva local o metastásica, que puede condicionar una infraestimación de las alteraciones locales asociadas a la RT, los diversos protocolos de quimioterapia y su administración conjunta o no con la RT y por último, la variedad de técnicas de irradiación utilizadas, fraccionamiento, campos y dosis $(14,17)$.

El objetivo que se plantea en este trabajo es analizar los efectos secundarios a largo plazo de la radioterapia postoperatoria y su repercusión en la función anorrectal.

\section{PACIENTES Y MÉTODOS}

Se revisaron retrospectivamente las historias de los pacientes intervenidos por cáncer de recto durante el periodo 1993-1998 en el Servicio de Cirugía del Hospital Lluís Alcanyís de Xàtiva. Se identificaron 68 pacientes que cumplían los siguientes criterios: tumor a menos de $15 \mathrm{~cm}$ del margen anal, sin invasión de órganos de vecindad, a los que se practicó una resección anterior de recto 
con anastomosis primaria sin estoma previo. De estos, se excluyeron 9 pacientes con metástasis en el momento de la intervención, 13 exitus por progresión de la enfermedad, 2 que requirieron un estoma temporal por dehiscencia de la sutura colorrectal, ya que esta complicación, por sí misma, podría alterar la función defecatoria, 1 que presentó un cáncer gástrico irresecable, y 6 que no se pudieron localizar. Los 37 pacientes restantes fueron incluidos en el estudio, dividiéndolos en dos grupos: uno formado por los 14 que habían sido tratados con quimio-radioterapia postoperatoria (QRT) y otro, considerado como control, con los 23 restantes que no habían recibido radioterapia. En el grupo control había dos pacientes en estadio 0 porque se trataba de grandes tumores vellosos degenerados (Tis) que requirieron una resección anterior.

El esquema de tratamiento de los 14 pacientes del grupo QRT fue el siguiente: 2 ciclos de quimioterapia con 5fluouracilo $\left(425 \mathrm{mg} / \mathrm{m}^{2}\right)$ y ácido folínico $\left(20 \mathrm{mg} / \mathrm{m}^{2}\right)$, seguido de radioterapia con 5-fluouracilo concomitante los tres primeros y los tres últimos días, hasta conseguir una dosis total de 45 Gy y añadiendo al finalizar una sobreimpresión en la zona presacra de 5,4 ó 9 Gy, según el volumen corporal. Se completó el tratamiento con 2 ciclos más de quimioterapia con 5-fluouracilo y ácido folínico.

La radioterapia se realizó con un acelerador lineal. La técnica de irradiación fue isocéntrica con 4 campos en la pelvis y con campos laterales en la sobreimpresión de la zona presacra, con un fraccionamiento de $180 \mathrm{cGy}$ por sesión hasta alcanzar la dosis completa. Para disminuir la posible toxicidad de la radioterapia se utilizaron como medidas proctectoras la irradiación en decúbito prono y la dieta astringente.

Durante el año 2002, se realizó una encuesta a todos los pacientes incluidos con el fin de evaluar el estado funcional anorrectal y se revisaron las historias para detectar las complicaciones mayores sufridas por estos pacientes tras el alta. De esta forma, se aseguraba un seguimiento mínimo de 3 años tras finalizar el tratamiento del cáncer de recto. La encuesta recogía: número de deposiciones diarias y nocturnas, consistencia (líquidas, blandas o duras), incontinencia y frecuencia de la misma (ocasional $\leq 1 \mathrm{vez}$ por semana; frecuente $>1$ vez por semana), manchado, necesidad de utilizar compresa, diferenciación de gas y heces, urgencia (si podían diferir o no la defecación más de 15 minutos), tenesmo, irritación perianal, sangrado, mucorrea y necesidad de medidas antidiarreicas (dieta, medicación). No se utilizaron los cuestionarios de calidad de vida específicos para el cáncer colorrectal, QLQ-CR 38, desarrollados por la EORTC, porque en el momento de realizar el estudio todavía no estaba validada su adaptación transcultural a España (18).

Se analizaron las complicaciones detectadas en el seguimiento y la función defecatoria según las respuestas a la encuesta realizada. La comparación de porcentajes entre ambos grupos se realizó mediante el test de Chi cuadrado.

\section{RESULTADOS}

En las características de la muestra, edad, sexo y altura del tumor, no existieron diferencias significativas entre ambos grupos, excepto para el estadio tumoral (Tabla I). Tampoco hubo diferencias significativas en las complicaciones postoperatorias entre ambos grupos. La hemorragia de la anastomosis colorrectal del grupo QRT cedió mediante electrogoagulación endoscópica y las 3 pequeñas fugas anastomóticas del grupo control, exteriorizadas por el drenaje y sin gran repercusión clínica, se resolvieron con tratamiento conservador, nutrición parenteral y antibióticos, en pocos días.

Los resultados de la encuesta (Tabla II) ponían de manifiesto que el grupo QRT tenía una media de deposiciones diarias $(3,3)$ significativamente superior $(p=0,03)$ a la del grupo control $(1,9)$. Un mayor porcentaje de pacientes, 30,8\%, del grupo QRT tenían necesidad de defecar durante la noche, frente a un 4,2\% del grupo control ( $\mathrm{p}=$ $0,04)$. También se detectaron diferencias significativas en la consistencia de las heces, el $46,2 \%$ de los pacientes que habían recibido quimio-radioterapia tenían las heces más blandas, frente al $13 \%$ del grupo control.

Referían incontinencia el 69,2\% de los pacientes del grupo QRT, predominantemente de forma ocasional, aunque un alto porcentaje de pacientes la referían también de forma frecuente. Sin embargo, de manera significativamente menor $(\mathrm{p}=0,002)$, sólo el $17,4 \%$ de pacientes del grupo control presentó incontinencia. Aunque sin diferencias estadísticamente significativas, se observó que un mayor porcentaje de los pacientes del grupo QRT precisaban llevar una compresa por seguridad, mientras que sólo el 13\% del grupo control la usaban. Tampoco se observaron diferencias en la incapacidad para discriminar los gases de las heces en ambos grupos.

La urgencia defecatoria era relativamente frecuente en ambos grupos. A pesar de no existir diferencias significativas entre ambos grupos, se objetivó que un mayor porcentaje de pacientes en el grupo que habían recibido quimio-radioterapia, $38,5 \%$, tenían dificultad para diferir la defecación más de 15 minutos, mientras que sólo el $21,7 \%$ del grupo control presentaban urgencia. Los pacientes irradiados también presentaron una mayor frecuencia de irritación perianal $(\mathrm{p}=0,04)$.

Pese a todas las alteraciones de la función anorrectal descritas, sólo un $31 \%$ de los pacientes de toda la muestra tomaron alguna medida, bien dietética, bien farmacológica, preferentemente loperamida, para controlar la frecuencia defecatoria.

Durante el seguimiento, 4 pacientes $(28,6 \%)$ del grupo QRT presentaron complicaciones mayores con frecuentes crisis suboclusivas al finalizar la radioterapia, debiendo ser reintervenidos 3 de ellos: en 2 pacientes se tuvo que practicar una resección ileal por estenosis actínica del intestino delgado y dilataciones de la anastomosis colorrectal por estenosis actínica; al otro paciente se le practicó una resección anterior tipo Hartmann por presentar una 
Tabla I. Descripción de la muestra

\begin{tabular}{lccc}
\hline & $P Q T-R T$ & No $R T$ & $p$ \\
\hline Hombre/Mujer & $8 / 6$ & $13 / 10$ & n.s \\
Edad* & $69(48-77)$ & $68.5(53-84)$ & n.s. \\
Altura tumor* & $10(6-12)$ & $10(6-15)$ & n.s. \\
Estadio & & & 0,03 \\
0 & - & 2 & \\
I & - & 7 & \\
II & 5 & 8 & \\
III & 9 & 6 & \\
Complicaciones postoperatorias & 6 & 10 & n.s. \\
Hemorragia anastomosis & 1 & - & \\
Íleo paralítico & 1 & - & \\
Seroma herida & 2 & 1 & \\
Infección herida & - & 4 & \\
Neumonía & 1 & - & \\
Infección urinaria & - & 1 & \\
Fuga anastomosis ${ }^{1)}$ & - & 3 & \\
\hline
\end{tabular}

*Mediana (límites); (1) Sin repercusión abdominal, resueltas con tratamiento conservador.

Tabla II. Función anorrectal a los 3 años de finalizar el tratamiento

\begin{tabular}{|c|c|c|c|}
\hline & $\begin{array}{c}\text { PQT-RT } \\
\text { (14 pacientes) }\end{array}$ & $\begin{array}{c}\text { No } R T \\
\text { (23 pacientes) }\end{array}$ & ) $p$ \\
\hline $\begin{array}{c}\text { Tipo de heces } \\
\text { Blandas } \\
\text { Normales }\end{array}$ & $\begin{array}{l}462 \% \\
53,8 \%\end{array}$ & $\begin{array}{l}13 \% \\
87 \%\end{array}$ & 0,04 \\
\hline$N^{\circ}$ deposiciones diarias* & $3,3(1-7)$ & $1,9(1-4)$ & 0,03 \\
\hline Deposiciones nocturnas & $30,8 \%$ & $4,2 \%$ & 0,04 \\
\hline $\begin{array}{l}\text { Incontinencia } \\
\text { No } \\
\text { Ocasional } \\
\text { Frecuente }\end{array}$ & $\begin{array}{l}30,8 \% \\
46,1 \% \\
23,1 \%\end{array}$ & $\begin{array}{c}82,6 \% \\
4,4 \% \\
13 \%\end{array}$ & 0,002 \\
\hline Uso de compresa & $30,8 \%$ & $13 \%$ & n.s. \\
\hline Incapacidad de diferenciar heces/gas & $30,8 \%$ & $30,4 \%$ & n.s. \\
\hline Urgencia defecatoria & $38,5 \%$ & $21,7 \%$ & n.s. \\
\hline Irritación perianal & $30,8 \%$ & $4,3 \%$ & 0,04 \\
\hline $\begin{array}{l}\text { Medidas antidiarreicas } \\
\text { Dieta } \\
\text { Medicación } \\
\text { No }\end{array}$ & $\begin{array}{l}30,8 \% \\
15,4 \% \\
53,8 \%\end{array}$ & $\begin{array}{c}13 \% \\
8,6 \% \\
78,3 \%\end{array}$ & n.s. \\
\hline
\end{tabular}

*Media (límites).

fístula anastomótica con un recto engrosado y rígido cuatro meses después de finalizar la radioterapia. En este paciente, actualmente, persiste una fístula estercorácea de débito bajo e intermitente a partir del remanente rectal. El resto de pacientes del grupo QRT y todos los del grupo control no han presentado en el seguimiento ninguna complicación mayor.

\section{DISCUSIÓN}

La radioterapia está admitida como un componente más del armamentario terapéutico del cáncer de recto, pretendiendo como objetivo primordial la disminución de la tasa de recidivas locales (2-11), siendo más eficaz cuando va asociada a la quimioterapia. Con la quimio-radioterapia se ha podido constatar una disminución de la tasa de recidivas y un aumento de la supervivencia (6). Pero diversas publicaciones $(1,3,5,15-17,19)$ han podido objetivar los efectos adversos de la misma, tanto en la radioterapia pre como postoperatoria.

La morbilidad aguda afecta en mayor o menor grado a la mayoría de los pacientes y se manifiesta con alteraciones gastrointestinales, hematológicas, dermatológicas y plexopatías lumbosacras, pero remite en unas semanas $(1,7,14,19)$. Aunque en nuestra serie, igual que en otras (5), no hemos tenido mortalidad, se describe en la literatura $(1,3,7)$ que un pequeño porcentaje de pacientes pueden tener cuadros graves, debidos a sepsis y problemas intestinales, que sitúan la tasa de mortalidad secundaria a la quimio-radioterapia entre 0,3 y $18 \%$. Esta morbi-mortalidad tan importante, los autores $(1,3,11,14)$ la atribuyen a factores del paciente (edad, diabetes, arteriosclerosis), al tipo de drogas usadas y a la técnica de irradiación.

Pero la irradiación provoca alteraciones que conllevan efectos adversos tardíos (1,14-16), como son oclusiones intestinales, enteritis y rectitis actínicas, cifrándose entre 4 y $15 \%$. En nuestra serie el porcentaje es algo mayor $28 \%$, puede que por el tamaño muestral. De los 4 pacientes con alteraciones actínicas sintomáticas, 3 debieron ser intervenidos, no quedando totalmente exentos de síntomas por las adherencias y los cambios actínicos permanentes del recto, llegándose incluso a provocar una fístula permanente del recto a la pared abdominal a pesar de haber excluido el tránsito mediante una intervención de Hartmann.

Las alteraciones funcionales del suelo pélvico no han sido bien documentadas, existiendo pocos estudios $(1,14-$ $16,20)$ que analicen las alteraciones funcionales a largo plazo. La mayor parte de los estudios están referidos a la supervivencia, recidiva local y alteraciones consiguientes a la técnica quirúrgica (14).

En nuestro estudio, coincidente con otros $(1,15,16)$, hemos podido comprobar la toxicidad de la quimio-radioterapia postoperatoria, que provoca una afectación importante de la función anorrectal, con heces más blandas, aumento del número de deposiciones diurnas y nocturnas, incontinencia, manchado e irritación perineal. Otras alteraciones descritas $(1,15)$, como la necesidad de usar compresa, la urgencia defecatoria y el uso de medidas antidiarreicas, aunque eran más frecuentes en el grupo QRT, no presentaban diferencias significativas, posiblemente por el tamaño muestral. Estas alteraciones funcionales han sido atribuidas $(1,14,15,20)$ a la disminución de la capacidad rectal, la rigidez del colon anastomosado y la alteración de las presiones anorrectales. 
El deterioro de la función anorrectal y las secuelas de las lesiones actínicas, junto con la posible necesidad de tratamientos médicos o quirúrgicos para mejorar los síntomas pueden alterar de forma significativa la calidad de vida de estos pacientes $(1,14)$.

Con la difusión de los ensayos clínicos con radioterapia preoperatoria realizados en la década de los 90 se ha sugerido que es preferible administrar la radioterapia preoperatoriamente $(4,6,10)$, porque así se podría conseguir una menor incidencia de efectos secundarios y complicaciones, además de ser menor la probabilidad de afectación del intestino delgado.

Sin embargo, con la estandarización de la excisión mesorrectal total en el cáncer de recto, surge ahora la controversia de la necesidad o no de radioterapia $(9,12,13,21,22)$, por la baja tasa de recidiva local con la EMT, similares a las que se obtienen con la quimio-radioterapia preoperatoria. La experiencia de Heald (12) pone de manifiesto que la EMT reduce las tasas de recidiva local en resecciones con carácter curativo al 2\% a los 10 años, lo que sugiere que el principal predictor de curación es la excisión completa del mesorrecto. La sobrevida es del $80 \%$ a los 10 años en las resecciones curativas. No obstante, tiene como lastre una tasa de complicaciones postoperatorias considerables, aunque no mayor que con otras técnicas y hasta un $17 \%$ de fístulas anastomóticas, por lo que se recomienda una ileosto- mía temporal si la anastomosis se sitúa a menos de $6 \mathrm{~cm}$ del margen anal $(12,23,24)$. Los únicos predictores significativos de recidiva local, en la experiencia de Heald (12), son la infiltración vascular, el estadio de Dukes y la infiltración del margen circunferencial.

Por tanto, teniendo en cuenta la morbilidad de la RT postoperatoria y la tasa de recidiva local con EMT y con quimio-radioterapia, la cuestión pendiente sería si la pauta estándar en el cáncer de recto es la EMT acompañada o no de quimio-radioterapia preoperatoria (4,24,25). La respuesta a esta cuestión se espera con los resultados de los ensayos en marcha actualmente. Por otra parte, se debería ser más selectivo y poner el énfasis en definir qué casos, analizados individualmente, pueden beneficiarse de un tratamiento neoadyuvante $(6,24,25)$, basándose en factores pronósticos.

Aumentar la supervivencia total y libre de enfermedad, disminuir la tasa de recidiva local y tener menos complicaciones postoperatorias no deben ser los únicos objetivos en el tratamiento del cáncer de recto. Hay que considerar ofrecer a nuestros pacientes la mejor calidad de vida posible. Así, deberíamos ser más críticos en la indicación de quimio-radioterapia postoperatoria ante el deterioro de la calidad de vida que puede implicar, dejándola posiblemente sólo para algunos pocos pacientes con muy alto riesgo de progresión. 